\title{
Evaluation of lingual cortical bone thickness of the mandibular third molars using CBCT
}

\author{
Mandibular üçüncü molarların lingual kortikal kemik kalınlıklarının KIBT ile \\ değerlendirilmesi
}

\author{
Gokhan Ozkan ${ }^{1 *}$, Umut Demetoglu²
}

${ }^{1}$ Aydın Adnan Menderes Üniversitesi, Ağız, Diş ve Çene Radyolojisi A.D., Aydın, Türkiye, Orcid': 0000-0003-4822-7303

${ }^{2}$ Aydın Adnan Menderes Üniversitesi, Ağız, Diş ve Çene Cerrahisi A.D., Aydın, Türkiye, Orcid²: 0000-0001-9960-3175

Atıf/Citation: Ozkan, G. \& Demetoglu, U (2020). Evaluation of Lingual Cortical Bone Thickness of the Mandibular Third Molars Using CBCT. Ege Üniversitesi Diş Hekimliği Fakültesi Dergisi, 41(2), 143-147.

\section{ABSTRACT}

Objectives: The aim of the study was to measure the lingual cortical bone thickness of the mandibular third molars, and to investigate its relationship with the tooth position.

Methods: Cone beam computerized tomography images which contained a total of 649 impacted mandibular third molars were included in the study. The closest distance of the crown and root tip of each tooth to the lingual soft tissues was measured. The impacted teeth were grouped as mesioangular, distoangular, vertical, horizontal, and buccolingual impaction. The teeth were also grouped as type $A, B$, and $C$ relation according to their distance to lingual soft tissues.

Results: Of the total 649 teeth, 590 (90.9\%) showed type A relation, 21 (3.2\%) type B relation and 38 (5.9\%) type C relation. Of these teeth, 302 were impacted in mesioangular, 141 in distoangular, 107 in horizontal, 86 in vertical, 13 in buccolingual position. No significant difference was found between the positions of the teeth and their distance to lingual soft tissues statistically.

Conclusion: Three dimensional radiographic evaluation may provide for predicting the complications before surgical procedures in very rare occasions in which the lingual bone thickness of mandibular third molars is suspected to be very thin that cannot be answered by $2 D$ imaging.

Keywords: Wisdom tooth, CBCT, cortical thickness, tooth displacement

\section{ÖZ}

Amaç: Bu çalışmanın amacı, mandibular üçüncü molarların lingual kortikal kemik kalınlıklarını ölçmek ve bu kalınlığın diş pozisyonu ile ilişkisini araştırmaktır.

Yöntem: Gömülü üçüncü molar dişleri içeren 649 konik ışınlı bilgisayarlı tomografi görüntüsü çalışmaya dahil edildi. Her bir dişin kron ve kök ucunun lingual yumuşak dokulara olan en yakın mesafesi ölçüldü. Gömülü dişler mezyoanguler, distoanguler, vertikal, horizontal ve bukkolingual pozisyonda gömülü olmak üzere gruplandırıldı. Dişler ayrıca yumuşak dokuya olan mesafelerine gore $A, B$ ve $C$ tipi olmak üzere gruplandırıldı.

Bulgular: Altı yüz kırk dokuz dişten, 590'ı (\%90,9) A tipi, 21'i $(\% 3,2)$ B tipi ve 38'i $(\% 5,9)$ C tipi ilişki gösterdi. Bu dişlerden 302'si mezyoanguler, 141'i distoanguler, 107'si horizontal, 86'sı vertikal, 13'ü bukkolingual pozisyonda gömülüydü. Dişlerin pozisyonları ve lingual yumuşak dokulara mesafeleri arasında istatistiksel olarak anlamlı bir fark bulunamadı.

Sonuç: Mandibular üçüncü molarların lingual kemik kalınlıklarının çok ince olduğundan şüphelenilen, iki boyutlu görüntülemenin yetersiz kaldığı çok nadir vakada, üç boyutlu radyografik değerlendirme cerrahi işlemlerden önce komplikasyon riskini öngörmeyi sağlayabilir.

Anahtar Kelimeler: Gömülü diş, KIBT, kortikal kalınlık, dişte yer değiştirme 


\section{INTRODUCTION}

The most commonly encountered impacted teeth among all teeth are third molars. The reasons to be impacted of a third molar may be local or systemic. Especially, mandibular third molars may stay impacted more often due to lack of adequate retromolar space, malpositioning of the dental germ, increased density in the surrounding bone, infection and hereditary causes. Therefore, problems such as pericoronitis, orthodontic, periodontal and prosthetic problems, tooth resorption and decay in the adjacent tooth, cystic and tumoral formations may occur. ${ }^{1,2}$ Extraction of mandibular third molar is one of the most common surgical procedures in the field of oral and maxillofacial surgery. This surgical procedure may cause complications such as infection, inferior alveolar nerve and laryngeal nerve injury, hemorrhage, alveolitis, osteomyelitis, mandibular fractures, trismus, displacement of the tooth (Figure 1) or tooth root to the surrounding cavities. ${ }^{3,4}$

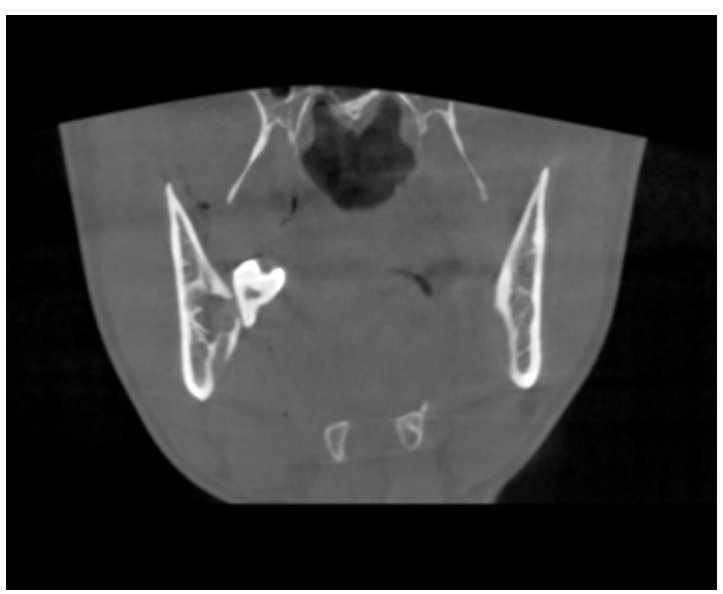

Figure 1. Lingually displaced third molar during extraction

These complications may occur due to the facts that lingual cortical bone is thin, the tooth is very close to the lingual soft tissues and the applied surgical technique is inadequate..$^{3-5}$ The determination of the location and condition of the surrounding anatomical structures before extracting the impacted teeth is extremely important. The most commonly used imaging tools to determine the position of third molars and their relation to the environment is panoramic radiography. However, it is known that in 2D imaging, data loss will occur and buccolingual assessment cannot be performed. In these cases in which these deficiencies cannot be solved, CBCT examination is preferred which offers the possibility of detailed examination of teeth and jaw structures in many sections and enables realistic measurement. The studies in the literature are generally aimed at determining the inferior nerve injury complications. ${ }^{6,7}$ There are only a few studies in the literature measuring lingual bone thickness. Emes et al. ${ }^{3}$, Tolstunov et al. ${ }^{8}$ and Ge et al. ${ }^{9}$ emphasized that the risk of perforation is high in cases where lingual bone thickness is thin. Menziletoglu et al. ${ }^{10}$ reported that thin or perforated lingual bone may result in displacement of the impacted tooth lingually.

In this study, it was aimed to measure the lingual cortical bone thickness, and to investigate its relationship with the tooth position.

\section{MATERIALS AND METHODS}

Ethical approval was obtained from Aydın Adnan Menderes University Ethical Committee (protocol no: 2016/1012). The cone beam computed tomography images (Planmeca ProMax 3D, Helsinki, Finland) which were obtained in our Oral and Maxillofacial Radiology Department for impacted lower third molars, dental implant planning, cyst and tumor operations, orthognathic surgery procedures were included in the study. The images were not included in the study in the situations such as the presence of dental cyst or tumor around the tooth to be examined, incomplete root development and ectopic tooth. After this assessment, a total of 649 images of the fully impacted mandibular third molars were evaluated retrospectively.

The relation of the teeth with the soft tissues was examined in three groups: Type A relation, the presence of some bone between the closest distance of tooth to the soft tissue and the soft tissue; B-type relation, $0 \mathrm{~mm}$ bone between tooth and soft tissue; C-type relation, the crown or root of tooth extended to soft tissue. For these assessments, the grouping criteria that were proposed by Emes et al. ${ }^{3}$ were used by modifying. The impacted teeth were grouped into mesioangular, distoangular, vertical, horizontal, and buccolingual impactions in the sections that were examined in the coronal plane according to Winter's classification. ${ }^{11}$

\section{IMAGE EVALUATION}

Images of $0.2 \mathrm{~mm}$ thickness on axial, coronal, sagittal and multiplanar sections were independently assessed by a radiologist via the Romexis software(Planmeca ProMax 3D, Helsinki, Finland) on a 17-inch computer screen. The point where the tooth root and crown is in the most lingual position and the point where the lingual bone 
ends was determined as reference points. The distance between these reference points was measured (Figure 2) as lingual bone thickness of the teeth and their relations with soft tissue were determined (Type A, B, C). The measurements were repeated two weeks later by the same examiner to evaluate intra-examiner agreement.
The mean of two measurements was recorded and evaluated. Any measurement on soft tissues was not performed since CBCT has a higher image noise and is not a suitable modality to evaluate the soft tissues. If the tooth had passed the lingual cortical bone border, it was considered to be in relation to soft tissues.

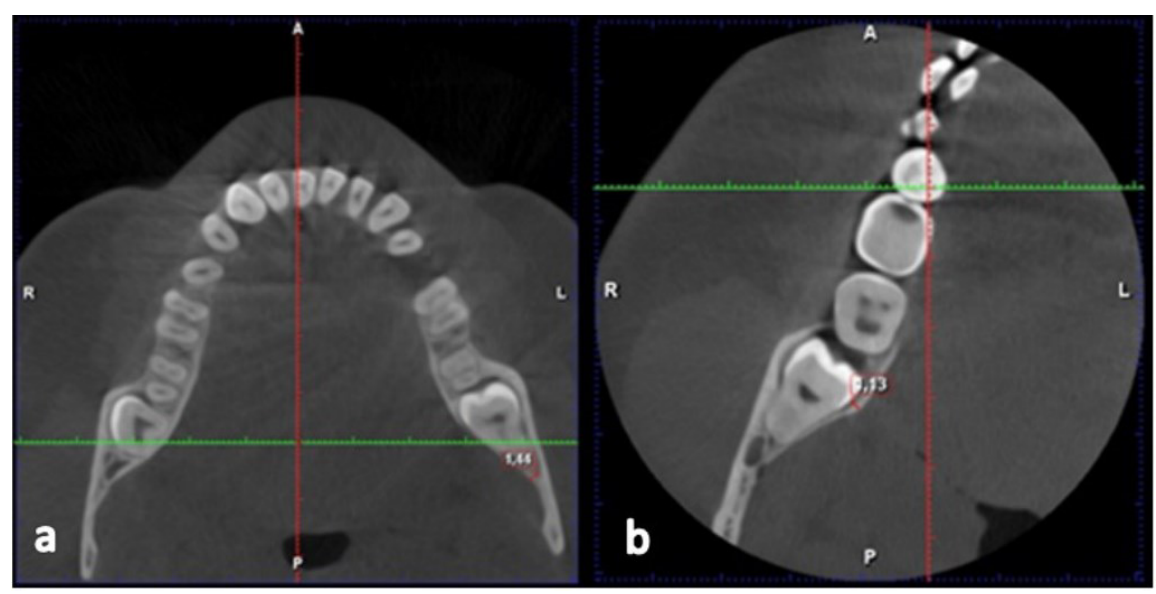

Figure 2. Measurement of root tip a) and crown b) to the soft tissues at axial plan of cone-beam computerized tomography

\section{STATISTICAL ANALYSIS}

The difference between the groups was determined using the chi-square test via the SPSS 17.0 program. The intra-examiner agreement was evaluated using the Kappa coefficient.

\section{RESULTS}

The intra-observer agreement for CBCT measurements was 0.93 , demonstrating almost perfect agreement. When the teeth were grouped according to their position of impaction, 302 teeth were impacted in mesioangular position, 141 teeth in distoangular position, 107 teeth in horizontal position, 86 teeth in vertical position and 13 teeth in buccolingual position. Of 302 impacted teeth in mesioangular position, 277 had type A relation, 9 had type $B$ relation and 16 had type $C$ relation. Of 141 impacted teeth in distoangular position, $125 \mathrm{had}$ type A relation, 6 had type $B$ relation and 10 had type $C$ relation. Of 107 impacted teeth in horizontal position, 99 had type A relation, 2 had type B relation and 6 had types $\mathrm{C}$ relation. Of 86 impacted teeth in vertical position, 79 had type A relation, 3 had type $B$ relation and 4 had type $C$ relation. Of 13 impacted teeth in bucco-lingual position, 10 had type A relation, 1 had type B relation and 2 had type $C$ relation. No statistically significant difference was detected between the impaction position of the teeth and the relation with the lingual soft tissues $\left(\chi^{2}=5.135\right.$, $\mathrm{p}=0.743)$. The results according to the angulation and thickness measurements were represented in Table 1.

Calculated distance at crown side was $1.35 \mathrm{~mm}$ and at root tip was $1.09 \mathrm{~mm}$. The mean of the closest distances of the teeth to the lingual soft tissues was calculated to be $1.22 \mathrm{~mm}$. According to this classification, 590 (90.9\%) of 649 teeth showed type A relation, 21 (3.2\%) showed type $\mathrm{B}$ relation and $38(5.9 \%)$ showed type $\mathrm{C}$ relation. In a total $9.1 \%(3.2 \%+5.9 \%)$ of teeth were observed to be in contact with the lingual soft tissues.

\section{DISCUSSION}

The extraction of third molars may lead to numerous complications. The presence of a thin cortical layer between the impacted mandibular third molars and lingual soft tissues or direct contact of the tooth with these tissues will increase the risk of complications. Various studies emphasized that the applied surgical technique had an impact on the possible complications that may occur during and after extraction. ${ }^{1,12}$ One of these complications is dental displacement into the surrounding spaces. When dental displacement occurs, attempting to reach the tooth may lead to greater tissue injuries which can negatively affect patient comfort. There is little information in the literature about dental displacement into the surrounding cavities related to cortical thickness. ${ }^{5}$ 
Table 1. The results according to the angulation and thickness measurements

\begin{tabular}{lllll}
\hline \multicolumn{7}{c}{ Types of relation } & & & \\
\hline Position of impaction & Type A n(\%) & Type B n(\%) & Type C n(\%) & Total \\
\hline Mezioanguler & $277(91.7)$ & $9(3)$ & $16(5.3)$ & 302 \\
\hline Distoanguler & $125(88.7)$ & $6(4.3)$ & $10(7)$ & 141 \\
\hline Horizontal & $99(92.5)$ & $2(1.9)$ & $6(5.6)$ & 107 \\
\hline Vertical & $79(91.9)$ & $3(3.5)$ & $4(4.6)$ & 86 \\
\hline Buccolingual & $10(77)$ & $1(7.7)$ & $2(15.3)$ & 13 \\
\hline Total & 590 & 21 & 38 & 649 \\
\hline
\end{tabular}

In the presented study, the magnitude of possible risk was attempted to be determined by measuring the closest distance of the crown and roots of lower third molars to the lingual soft tissues via CBCT. There are rare studies which examined the relationship between mandibular third molars, teeth angle and the thickness of the bone between the lingual soft tissues. Menziletoglu et al. ${ }^{10}$ declared that as the buccolingual and mesiodistal angulations increase, lingual bone thickness decreases. Tolstunov et al. ${ }^{8}$ reported that mandibular third molar angle may be associated with lingual bone thickness and suggested that the risk of perforation was higher in the teeth with horizontal and mesioangular placement. In the study by Ge et al. ${ }^{9}$, they reported that lingual bone thickness was below $1 \mathrm{~mm}$ in the vast majority of the cases $(87.3 \%)$. Also, Emes et al. ${ }^{3}$ obtained similar results. The mean lingual bone thickness was found to be $1.22 \mathrm{~mm}$ in our study. 1.09 at root tip and 1.35 at crown side. This result was found to be higher than the results of the other two studies. This difference may be caused by the difference of studied population, a number of people participated in the study and the used classification technique. In addition, the study design of this study is also different than other studies. Both crown and root tip distances to the lingual soft tissues were measured separately. The higher distance measurements among researches may also result from different study designs. The bone thickness at crown and root tip that was determined in the studied population was still very thin and if the necessary precautions are not taken, the tooth may be displaced into the surrounding cavities. This risk is much higher, especially in cases which have type $\mathrm{B}$ and type $\mathrm{C}$ relations. In the present study $9.1 \%$ of fully impacted mandibular third molars were found direct relation to the lingual soft tissue. However no statistical differences were found between angulation of teeth and lingual bone thickness and soft tissue tooth contact.

Nickening et al. ${ }^{13}$ and Kamburoğlu et al. ${ }^{14}$ reported that most of the patients had at least one lingual undercuts in the right or left mandibular molar region. Although lingual undercut assessment is not in the evaluation parameters of the present study, lingual undercut is an anatomic property that also affect the distance between the mandibular third molar and lingual soft tissues.

\section{CONCLUSION}

Three-dimensional radiographic evaluation may provide for predicting the risk of complications in very rare occasions in which the lingual bone thickness is suspected to be very thin that cannot be answered by $2 \mathrm{D}$ imaging. In the situations with high risk of complications, the surgeon must operate more sensitively and should not exert excessive force during tooth extraction. 


\section{REFERENCES}

[1] Mavrodi A, Ohanyan A, Kechagias N, Tsekos A, Vahtsevanos K. Influence of two different surgical techniques on the difficulty of impacted lower third molar extraction and their post-operative complications. Med Oral Patol Oral Cir Bucal 2015; 20: e640-644.

[2] de Boer MP, Raghoebar GM, Stegenga B, Schoen PJ, Boering G. Complications after mandibular third molar extraction. Quintessence Int 1995; 26: 779784.

[3] Emes Y, Oncu B, Aybar B, et al. Measurement of the Lingual Position of the Lower Third Molar Roots Using Cone-Beam Computed Tomography. J Oral Maxillofac Surg 2015; 73: 13-17.

[4] Guo Y, Xu DD, Lv K, Wan QL, Li ZB, Li Z. Use of Computer-Assisted Navigation in the Retrieval of Accidentally Displaced Third Molars. J Oral Maxillofac Surg 2016; 74: 889-894.

[5] Aznar-Arasa L, Figueiredo R, Gay-Escoda C. Iatrogenic displacement of lower third molar roots into the sublingual space: report of 6 cases. J Oral Maxillofac Surg 2012; 70: e107-115.

[6] Korkmaz YT, Kayımaz S, Senel FC, Atasoy KT, Gumrukcu Z. Does additional cone beam computed tomography decrease the risk of inferior alveolar nerve injury in high-risk cases undergoing third molar surgery? Does CBCT decrease the risk of IAN injury? Int J Oral Maxillofac Surg 2017; 46: 628-635.

[7] Hasani A, Ahmadi Moshtaghin F, Roohi P, Rakhshan V. Diagnostic value of cone beam computed tomography and panoramic radiography in predicting mandibular nerve exposure during third molar surgery. Int J Oral Maxillofac Surg 2017; 46: 230-235.
[8] Tolstunov L, Brickeen M, Kamanin V, Susarla SM, Selvi F. Is the angulation of mandibular third molars associated with the thickness of lingual bone? $\mathrm{Br} \mathrm{J}$ Oral Maxillofac Surg 2016; 54: 914-919.

[9] Ge J, Zheng JW, Yang C, Qian WT. Variations in the buccal-lingual alveolar bone thickness of impacted mandibular third molar: our classification and treatment perspectives. Sci Rep 2016; 6: 16375.

[10] Menziletoglu D, Tassoker M, Kubilay-Isik B, Esen A. The assesment of relationship between the angulation of impacted mandibular third molar teeth and the thickness of lingual bone: A prospective clinical study. Med Oral Patol Oral Cir Bucal 2019;24:e130-e135.

[11] Winter G.B. Impacted mandibular third molars. St Louis: American Medical Book Co., 1926, 241-279.

[12] Øyri H, Bjørnland T, Barkvoll P, Jensen JL. Mandibular third molar surgery in 396 patients at a Norwegian university clinic: Morbidity recorded after 1 week utilizing an e-infrastructure for clinical research. Acta Odontol Scand 2016; 74: 148-154.

[13] Nickenig HJ, Wichmann M, Eitner S, Zöller JE, Kreppel M. Lingual concavities in the mandible: a morphological study using cross-sectional analysis determined by CBCT. J Craniomaxillofac Surg 2015; 43: 254-259.

[14] Kamburoğlu K, Acar B, Yüksel S, Paksoy CS. CBCT quantitative evaluation of mandibular lingual concavities in dental implant patients. Surg Radiol Anat 2015; 37: 1209-1215. 